\title{
Regional Wage Differentials and Industrial Wage Discrimination\#
}

\author{
Marvin M. Smith*
}

\section{INTRODUCTION}

The evidence advanced in most of the recent empirical research assessing the progress in the relative economic status of minorities during the post-World War II period seems to suggest definite but (at times) differential rates of improvement on a spatial basis. ${ }^{1}$ These encouraging changes were particularly evident during the period of the late 1960's when numerous formal attempts were undertaken-primarily through legislative action - to eradicate (racial) discrimination as it existed in the labor market.

While researchers are seemingly in agreement as to the uneven pattern of advances for black males, the sources of such differential effects across regions remain a point of contention (see Table 1 ). ${ }^{2}$ Two possible explanations for this phenomenon, which have received some attention in the literature, associate these differential changes, in part, to relative tightness of (local) labor markets and the increased antidiscrimination activity undertaken in the latter half of the 1960's. ${ }^{3}$ While these two forces no doubt greatly influenced the nature of the changes in racial wage differentials, they have been less than satisfactory in accounting for the observed regional phenomenon. In addition to these explanations, a number of studies taking somewhat different approaches have also attempted to explain this occurrence. Recent regression studies (see, e.g., Vroman [15]) have been successful in documenting the existence of statistically significant time trends in the relative earnings of blacks since 1965, but they were unable to identify the sources of the trends. Other studies have stressed changes in productivity differences between black and white workers, in the form of racial differences in the quantity and quality of schooling, as the major source of the relative changes which have occurred (see Welch [16]). Notwithstanding the valuable insight gained from these earlier studies, their ". . . explanations do not appear to deal fully with the important regional disparities in relative [earnings] gains ... [as reflected in Table 1]" (Flanagan [5, p. 494]).

\footnotetext{
*Economic Studies Program. The Brookings Institution.

\# This study was partially supported by a grant from the Rockefeller Foundation. The author gratefully acknowledges, without implication, the helpful criticism and suggestions at an earlier stage of Professors Ronald Ehrenberg and Rober $S$. Smith of Cornell University. A more detailed version of this paper was presented at the Western Fconomic Assoxiation Conference in Anaheim, California, June 1977. The view's expressed here are those of the author and not necessarily those of the officers, trustees, or other staff members of The Brokings Institution or the Rockefeller Foundation.
} 
TABLE 1

RELATIVE WAGE AND SALARY INCOME OF BLACK MALES BY REGION, 1959 AND 1969

\begin{tabular}{llc}
\hline REGION & 1959 & 1969 \\
\hline Northeast & $74.9 *$ & 74.9 \\
South & 43.5 & 58.7 \\
West & 72.8 & 79.9 \\
North Central & 81.7 & 81.5 \\
\hline
\end{tabular}

SOURCE: U.S. Bureau of the Census, Current Population Reports, series p. 60.

*full time, year round workers

This paper presents an alternative hypothesis which might provide some insight into the uneven pattern of changes across regions. This view centers on the magnitude of industry discrimination coefficients and the regional distribution of these industries coupled with the relative distribution of minorities (in this case black males) in the industries. Thus, it is postulated that these regional differences in part might be a reflection of some regions gaining or losing over time a larger share of industries with relatively large discrimination coefficients; while these industries, in turn, are employing an increasing number of minorities (i.e., black males).

\section{METHODOLOGY}

The research design employed in this paper makes use of both descriptive statistical techniques and regression analysis. The use of two regional economic coefficients, namely, the coefficient of specialization and the location quotient as well as the shift-share technique provide essential information on the employment environment and the structural relationships in the four (census) regions. The utilization of regression analysis, on the other hand, enables the estimation of industry discrimination coefficients which are necessary for the assessment of the hypothesis advanced here.

DESCRIPTIVE STATISTICAL TECHNIQUES. The coefficient of specialization and the location quotient were calculated for the four census regions on a nine-ind ustry classification ${ }^{4}$ using both 1960 and 1970 census data. The coefficient of specialization measures the extent of deviation in the distribution of employment by industry classes in a given region from such distribution for the U.S. ${ }^{5}$

In order to identify those industries responsible for the magnitudes of the coefficients of specialization for the various regions, the location quotients for the various industries in the region are consulted. ${ }^{6}$

Finally, shift-share analysis ${ }^{7}$ was used to analyze the changes in black male employment in the four regions on a nine-industry classification over the period 1960-1970. This technique ${ }^{8}$ has customarily been employed to partition regional growth rates into two "effects," viz., a composition or industry-mix effect and a local market or share effect. If employment is used as the unit of measure and the nation as the base, then in essence, 
these two effects (taken together) measure in employment the change that would have occurred had each of its industries, and therefore, the regional total, grown at the same rate as employment nationally. ${ }^{\mathbf{9}}$

REGRESSION ANALYSIS. Industry discrimination coefficients are estimated via regression analysis. ${ }^{10}$ The data utilized are extracted from the May 1973 Current Population Survey tape. These discrimination coefficients are obtained by decomposing the gross industrial mean wage differential, $\log \bar{W}_{\mathrm{W}}^{\mathrm{j}}-\log \overline{\mathrm{W}}_{\mathrm{B}}^{\mathrm{j}}$ (which, in turn, are obtained from hourly wage rate regressions corresponding to equation 1 that were estimated separately for blacks and whites on a nine-industry classification ${ }^{1 \mathbf{1}}$ ), into that part resulting from differences in endowment and the portion attributable to discrimination.

\section{(1) $\log \mathrm{W}_{\mathrm{i}(\mathrm{W})}^{\mathrm{j}}=\Omega\left(\mathrm{H}_{1}^{\mathrm{j}}, \mathrm{P}_{\mathrm{i}}^{\mathrm{j}}, \mathrm{L}_{\mathrm{i}}^{\mathrm{j}}\right)$}

where $W_{i}^{j}=$ hourly wage-rate of the $i$ th individual in the $j$ th industry with $\mathrm{B}(\mathrm{W})$ indicating that the individual is black (white); and $\mathrm{H}_{\mathrm{i}}^{\mathbf{j}}, \mathrm{P}_{\mathbf{i}}^{\mathbf{j}}$, and $\mathrm{L}_{\mathbf{i}}^{\mathbf{j}}$ are vectors of his human capital investments, personal attributes, and locational characteristics, respectively. ${ }^{12}$

In addition to the individual industry discrimination coefficients, a race coefficient from pooled data (for blacks and whites) by means of a dummy variable is estimated for comparative purposes.

\section{RESULTS}

\section{Qualitative}

The computed coefficients of specialization are reported in Table 2 . As indicated in Table 2, these coefficients were computed on the basis of black male employment as well as total male employment. Due to the reliance upon only a nine-industry classification, the absolute magnitudes of the coefficients for both black males and total males are somewhat distorted. However, for our purposes, we are mainly interested in the relative magnitudes of the coefficients pertaining to black male employment and they reveal some rather striking impressions. In terms of black male employment, the southern region shows the largest relative change in its specialization coefficient from 1960-1970, while the western region registers the smallest change. Although these coefficients are not generally regarded as reflecting the patterns of migration, it seems reasonable to suggest that one possible underlying cause of the changes in the coefficients is indeed migration. This seems quite plausible when considering the aforementioned change in the coefficient of specialization for the southern region. Moreover, the relative changes in the remaining regions, by and large, tend to support the migratory patterns during this period.

In order to identify those industries responsible for the magnitudes of these coefficients, we turn to the location quotients presented in Table 3. As far as the southern region is concerned, education and construction are the two industries which have contributed the most to the coefficient of specialization in both 1960 and 1970 when considering the employment of black males only. The location quotient identifies other transportation, 
TABLE 2

SPECIALIZATION COEFFICIENT

\begin{tabular}{lcc}
\hline REGION & 1960 & 1970 \\
\hline NORTHEAST & $0.02209^{*}$ & 0.01075 \\
SOUTH & $(0.02109)^{* *}$ & $(0.00928)$ \\
& 0.02109 & 0.00786 \\
WEST & $(0.02086)$ & $(0.00536)$ \\
& 0.01607 & 0.01002 \\
NORTH CENTRAL & $(0.01024)$ & $(0.01625)$ \\
& 0.04044 & 0.03341 \\
& $(0.00056)$ & $(0.00698)$ \\
\hline
\end{tabular}

* BLACK MALES ONLY

** TOTAL MALES

nondurable manufacturing, and public administration as responsible for the magnitude of the coefficient for the northern region in 1960; but singles out other transportation, public administration and retail trade in 1970. The west appears to have been more specialized in public administration and other utilities in 1960 but a switch to durable manufacturing and public administration occurred in 1970. Finally, durable manufacturing and public administration contributed the most to the coefficients of specialization in 1960 and 1970 for the north-central region.

Consider now the results of the shift-share analysis of black male employment in our study-group industries from 1960-1970. As can be seen in Table 4, the overall employment of black males grew in all regions over the period with the greatest percentage growth occurring in the west and the smallest in the southern region. Moreover, all regions enjoyed "a favorable distribution of fast growing industries, i.e., the national growth rates of these industries are higher than the aggregate national growth rate" 13 (which is $11.29 \%$ ). The similarities, however, stop here. The most noticeable difference among the four regions is their regional shares component. The southern region experienced an overall loss in regional share (of employment). As is evident, the southern region lost share in all but two of the nine study-group industries (namely, nondurable manufacturing and public administration). This implies that the other seven industries in the southern region were growing at a slower rate than their national (industry) average. As far as the other regions are concerned, the northeast lost share in durable manufacturing and nondurable manufacturing; the western region lost share in construction; and the north-central region lost share in nondurable manufacturing, other utilities and public administration. It should be pointed out that some regions enjoyed (relatively) sizeable gains in regional shares of employment in certain industries. The northeast region registered a relatively large gain in regional share of the retail trade industry. The southern region experienced a large gain in regional share of nondurable manufacturing. The west region, as the northeast, gained a large share of the retail trade industry. The north- 
TABLE 3

LOCATION QUOTIENT

\begin{tabular}{|c|c|c|c|c|c|c|c|c|}
\hline \multirow{2}{*}{$\begin{array}{l}\text { REGION } \\
\text { YEAR } \\
\text { INDUSTRY }\end{array}$} & \multicolumn{2}{|c|}{ NORTHEAST } & \multicolumn{2}{|c|}{ SOUTH } & \multicolumn{2}{|c|}{ WEST } & \multicolumn{2}{|c|}{$\begin{array}{c}\text { NORTH } \\
\text { CENTRAL }\end{array}$} \\
\hline & 1960 & 1970 & 1960 & 1970 & 1960 & 1970 & 1960 & 1970 \\
\hline CONSTR & $\begin{array}{c}0.792 * \\
(0.820)^{* *}\end{array}$ & $\begin{array}{c}0.774 \\
(0.889)\end{array}$ & $\begin{array}{c}1.143 \\
(1.118)\end{array}$ & $\begin{array}{c}1.262 \\
(1.239)\end{array}$ & $\begin{array}{c}1.142 \\
(1.056)\end{array}$ & $\begin{array}{c}0.837 \\
(0.980)\end{array}$ & $\begin{array}{c}0.689 \\
(0.791)\end{array}$ & $\begin{array}{c}0.628 \\
(0.862)\end{array}$ \\
\hline DURMAN & $\begin{array}{c}1.037 \\
(1.151)\end{array}$ & $\begin{array}{c}0.852 \\
(1.070)\end{array}$ & $\begin{array}{c}0.759 \\
(0.621)\end{array}$ & $\begin{array}{c}0.768 \\
(0.705)\end{array}$ & $\begin{array}{c}0.889 \\
(0.902)\end{array}$ & $\begin{array}{c}0.820 \\
(0.845)\end{array}$ & $\begin{array}{c}1.719 \\
(1.285)\end{array}$ & $\begin{array}{c}1.778 \\
(1.333)\end{array}$ \\
\hline NONDUR & $\begin{array}{c}1.316 \\
(1.234)\end{array}$ & $\begin{array}{c}1.040 \\
(1.149)\end{array}$ & $\begin{array}{c}0.936 \\
(1.049)\end{array}$ & $\begin{array}{c}1.109 \\
(1.157)\end{array}$ & $\begin{array}{c}0.650 \\
(0.679)\end{array}$ & $\begin{array}{l}0.583 \\
(0.633)\end{array}$ & $\begin{array}{l}1.033 \\
(0.913)\end{array}$ & $\begin{array}{c}0.843 \\
(0.925)\end{array}$ \\
\hline OTRANS & $\begin{array}{c}1.493 \\
(1.155)\end{array}$ & $\begin{array}{c}1.427 \\
(1.101)\end{array}$ & $\begin{array}{c}0.965 \\
(1.052)\end{array}$ & $\begin{array}{c}0.919 \\
(1.021)\end{array}$ & $\begin{array}{l}1.205 \\
(1.054)\end{array}$ & $\begin{array}{c}1.113 \\
(1.023)\end{array}$ & $\begin{array}{c}0.784 \\
(0.932)\end{array}$ & $\begin{array}{c}0.750 \\
(0.877)\end{array}$ \\
\hline OUTILS & $\begin{array}{c}0.942 \\
(0.972) \\
\end{array}$ & $\begin{array}{c}0.852 \\
(0.942) \\
\end{array}$ & $\begin{array}{c}0.998 \\
(1.066)\end{array}$ & $\begin{array}{l}1.101 \\
(1.115)\end{array}$ & $\begin{array}{c}1.402 \\
(1.042)\end{array}$ & $\begin{array}{c}1.168 \\
(1.014) \\
\end{array}$ & $\begin{array}{c}0.980 \\
(0.940)\end{array}$ & $\begin{array}{c}0.834 \\
(0.924)\end{array}$ \\
\hline WTRADE & $\begin{array}{c}1.067 \\
(1.040)\end{array}$ & $\begin{array}{c}1.046 \\
(0.979)\end{array}$ & $\begin{array}{c}1.011 \\
(0.978)\end{array}$ & $\begin{array}{c}1.049 \\
(1.018)\end{array}$ & $\begin{array}{c}0.815 \\
(1.068)\end{array}$ & $\begin{array}{c}0.908 \\
(1.057)\end{array}$ & $\begin{array}{c}0.849 \\
(0.937)\end{array}$ & $\begin{array}{c}0.868 \\
(0.966)\end{array}$ \\
\hline RTRADE & $\begin{array}{c}1.058 \\
(0.990)\end{array}$ & $\begin{array}{c}1.078 \\
(0.987)\end{array}$ & $\begin{array}{c}1.019 \\
(1.050)\end{array}$ & $\begin{array}{c}0.998 \\
(1.017)\end{array}$ & $\begin{array}{c}0.953 \\
(1.028)\end{array}$ & $\begin{array}{c}1.100 \\
(1.075)\end{array}$ & $\begin{array}{c}0.928 \\
(0.946)\end{array}$ & $\begin{array}{c}0.895 \\
(0.950)\end{array}$ \\
\hline EDUCAT & $\begin{array}{c}0.646 \\
(0.972)\end{array}$ & $\begin{array}{c}0.759 \\
(1.022)\end{array}$ & $\begin{array}{c}1.171 \\
(0.907)\end{array}$ & $\begin{array}{c}1.142 \\
(0.871)\end{array}$ & $\begin{array}{c}1.004 \\
(1.244)\end{array}$ & $\begin{array}{c}1.153 \\
(1.182)\end{array}$ & $\begin{array}{c}0.734 \\
(1.000)\end{array}$ & $\begin{array}{c}0.828 \\
(1.007)\end{array}$ \\
\hline PUBADM & $\begin{array}{c}1.183 \\
(0.983)\end{array}$ & $\begin{array}{c}1.105 \\
(0.981)\end{array}$ & $\begin{array}{c}0.731 \\
(1.128)\end{array}$ & $\begin{array}{c}0.846 \\
(1.147)\end{array}$ & $\begin{array}{c}2.149 \\
(1.255)\end{array}$ & $\begin{array}{c}1.745 \\
(1.218)\end{array}$ & $\begin{array}{c}1.292 \\
(0.766)\end{array}$ & $\begin{array}{c}1.018 \\
(0.737)\end{array}$ \\
\hline
\end{tabular}

* BLACK MALES ONLY

** TOTAL MALES

central region, on the other hand, enjoyed the largest relative gain in regional share of any industry; with its increasing share occurring in durable manufacturing.

All told, the tenor of the results of the shift-share analysis, while not surprising, provides additional information necessary to test the hypothesis. A complete evaluation of the hypothesis, however, requires the use of the estimated industry discrimination coefficients.

In Table 5 the individual industry discrimination coefficients ${ }^{14}$ are presented along with the dummy variable discrimination coefficientreferred to as the "market" discrimination coefficient. The "market" coefficient, by and large, represents the average industry wage discrimination occurring across industries and thus will be used as the benchmark with which to determine the relative size of the industry discrimination coefficients.

The strategy to be employed in the (qualitative) examination of the hypothesis advanced here is to check the location quotients for the various industries (in 1970) in the four regions and take note of whether the 
TABLE 4

SHIFT-SHARE ANALYSIS: BLACK MALES (STUDY-GROUP INDUSTRIES)

\begin{tabular}{|c|c|c|c|c|c|c|c|}
\hline \multirow[b]{2}{*}{ INDLSTRY } & \multicolumn{2}{|c|}{ EMPLOYMENT } & \multirow[b]{2}{*}{$\begin{array}{c}\mathrm{R} \\
\text { ABSOLUTE } \\
\text { CHANGE } \\
1 \text { TO } 2\end{array}$} & \multirow[b]{2}{*}{$\begin{array}{c}\text { P } \\
\text { PERCENT } \\
\text { CHANGE } \\
1 \text { TO } 2\end{array}$} & \multicolumn{3}{|c|}{ COMPONENTS OF EMPLOYMENT CHANGE } \\
\hline & YEAR 1 & YEAR 2 & & & $\begin{array}{c}\text { N } \\
\text { NATIONAL } \\
\text { GROWTH } \\
\text { EFFECT }\end{array}$ & $\begin{array}{c}\text { M } \\
\text { INDUSTRY } \\
\text { MIX } \\
\text { EFFECT }\end{array}$ & $\begin{array}{c}\text { S } \\
\text { REGIONAL } \\
\text { SHARES }\end{array}$ \\
\hline \multicolumn{8}{|c|}{ REGION NEAST } \\
\hline CONSTR & 44811 & 59210 & 14399.00 & 32.13 & 5061.13 & 2951.57 & 6386.30 \\
\hline DLRMAN & 108212 & 140692 & 32480.00 & 30.02 & 12221.89 & 28970.84 & -8712.73 \\
\hline NONDLR & 77192 & 92306 & 15114.00 & 19.58 & 8718.37 & 16020.19 & -9624.56 \\
\hline OTRANS & 37870 & 56947 & 19077.00 & 50.37 & 4277.19 & 9820.47 & 4979.34 \\
\hline OL'TII.S & 11185 & 14710 & 3525.00 & 31.52 & 1263.28 & 1728.63 & 533.09 \\
\hline WTRADE & 20745 & 34961 & 14216.00 & 68.53 & 2343.02 & 8011.87 & 3861.11 \\
\hline RTRADE & 72669 & 96766 & 24097.00 & 33.16 & 8207.52 & 1929.25 & 13961.23 \\
\hline EDLC.AT & 11085 & 26955 & 15870.00 & 143.17 & 1251.98 & 7678.38 & 6939.64 \\
\hline PLBADM & 42600 & 65441 & 22841.00 & 53.62 & 4811.41 & 13680.18 & 4349.41 \\
\hline TOTAI. & 426369 & 587988 & 161619.00 & 37.91 & 48155.79 & 90790.38 & 22672.83 \\
\hline \multicolumn{8}{|c|}{ RECIONAI SOLTH } \\
\hline CONSTR & 214475 & 247590 & 33115.00 & 15.44 & 24223.65 & 14126.83 & -5235.47 \\
\hline DLRMAN & 262577 & 325475 & 62898.00 & 23.95 & 29656.48 & 70297.90 & -37056.38 \\
\hline NONDUR & 182026 & 252487 & 70461.00 & 38.71 & 20558.73 & 37777.12 & 12125.15 \\
\hline OTRANS & 81188 & 94157 & 12969.00 & 15.97 & 9169.69 & 21053.72 & -17254.41 \\
\hline OLTIISS & 39280 & 48779 & 9499.00 & 24.18 & 4436.44 & 6070.69 & -1008.13 \\
\hline WTRADE & 65161 & 89890 & 24729.00 & 37.95 & 7359.54 & 25165.66 & -7796.20 \\
\hline RTRADE & 232114 & 229863 & -2251.00 & -0.97 & 26215.87 & 6159.06 & -34625.93 \\
\hline EDUCAT & 66591 & 104029 & 27438.00 & 56.22 & 7521.05 & 46126.38 & -16209.43 \\
\hline PLBADM & 87303 & 128648 & 41345.00 & 47.36 & 9860.34 & 28035.70 & 3448.95 \\
\hline TOTAL. & 1230715 & 1520918 & 290203.00 & 23.58 & 139001.78 & 254813.06 & -103611.84 \\
\hline
\end{tabular}


TABLE 4 (cont.)

\begin{tabular}{|c|c|c|c|c|c|c|c|}
\hline \multirow[b]{2}{*}{ INDUSTRY } & \multicolumn{2}{|c|}{ EMPLOYMENT } & \multirow[b]{2}{*}{$\begin{array}{c}\mathrm{R} \\
\text { ABSOLUTE } \\
\text { CHANGE } \\
\text { l to } 2\end{array}$} & \multirow[b]{2}{*}{$\begin{array}{c}\text { P } \\
\text { PERCENT } \\
\text { CHANGE } \\
\text { l to } 2\end{array}$} & \multicolumn{3}{|c|}{ COMPONENTS OF EMPLOYMENT CHANGE } \\
\hline & YEAR 1 & YEAR 2 & & & $\begin{array}{c}\text { N } \\
\text { NATIONAL } \\
\text { GROWTH } \\
\text { EFFECT }\end{array}$ & $\begin{array}{c}\text { M } \\
\text { INDUSTRY } \\
\text { MIX } \\
\text { EFFECT }\end{array}$ & $\begin{array}{c}\text { S } \\
\text { REGIONAL } \\
\text { SHARES }\end{array}$ \\
\hline \multicolumn{8}{|l|}{ REGION WEST } \\
\hline CONSTR & 21081 & 23275 & 2194.00 & 10.41 & 2380.97 & 1388.54 & -1575.51 \\
\hline DURMAN & 30268 & 49234 & 18966.00 & 62.66 & 3418.59 & 8103.44 & 7443.97 \\
\hline NONDUR & 12453 & 18798 & 6345.00 & 50.95 & 1406.49 & 2584.46 & 2354.05 \\
\hline OTRANS & 9977 & 16146 & 6169.00 & 61.83 & 1126.84 & 2587.24 & 2454.92 \\
\hline OUTILS & 5435 & 7325 & 1890.00 & 34.77 & 613.85 & 839.97 & 436.18 \\
\hline WTRADE & 5171 & 11031 & 5860.00 & 113.32 & 584.03 & 1997.08 & 3278.89 \\
\hline RTRADE & 21377 & 35886 & 14509.00 & 67.87 & 2414.40 & 567.23 & 11527.37 \\
\hline EDUCAT & 5620 & 14878 & 9258.00 & 164.73 & 634.74 & 3892.87 & 4730.38 \\
\hline PUBADM & 25259 & 37574 & 12315.00 & 48.75 & 2852.85 & 8111.45 & 1350.70 \\
\hline TOTAL & 136641 & 214147 & 77506.00 & 56.72 & 15432.77 & 30072.29 & 32000.94 \\
\hline \multicolumn{8}{|c|}{ REGION NCENT } \\
\hline CONSTR & 41406 & 49976 & 8570.00 & 20.70 & 4676.56 & 2727.29 & 1166.15 \\
\hline DURMAN & 190465 & 305712 & 115247.00 & 60.51 & .21511 .86 & 50991.86 & 42743.27 \\
\hline NONDUR & 64340 & 77855 & 13515.00 & 21.01 & 7266.81 & 13352.93 & -7104.74 \\
\hline OTRANS & 21118 & 31152 & 10034.00 & 47.51 & 2385.15 & 5476.33 & 2172.52 \\
\hline OUTILS & 12355 & 14975 & 2620.00 & 21.21 & 1395.42 & 1909.45 & -684.88 \\
\hline WPRADE & 17519 & 30161 & 12642.00 & 72.16 & 1978.66 & 6765.97 & 3897.37 \\
\hline RTRADE & 67667 & 83641 & 15974.00 & 23.61 & 7642.58 & 1795.52 & 6535.90 \\
\hline EDUCAT & 13359 & 30600 & 17241.00 & 129.06 & 1508.82 & 9253.54 & 6478.65 \\
\hline PUBADM & 49413 & 62711 & 13298.00 & 26.91 & 5580.90 & 15868.05 & -8150.95 \\
\hline TOTAL & 477642 & 686783 & 209141.00 & 43.79 & 53946.94 & 108140.94 & 47053.30 \\
\hline
\end{tabular}

National Growth Rate $=11.29 \%$ 
regions are gaining or losing share of these industries while keeping in mind the relative values of their discrimination coefficient. The presumption being that a region, e.g., which has a more than average number of industries with relatively large discrimination coefficients and is gaining share in some of them will tend to experience a decline in its black-white wage and salary ratio relative to other regions.

In applying this strategy to the southern region we find the best support for the hypothesis. In the south region, the location quotient identified education and construction as those industries contributing the most to the region's coefficient of specialization. Moreover, both industries have relatively small discrimination coefficients. But perhaps the most compelling feature is that the southern region lost share in seven of its nine industries of which three had relatively large discrimination coefficients. According to the hypothesis, the southern region should have experienced a market increase in the relative wage and salary income of black males which is confirmed in Table 1.

The west region was shown to be more specialized in durable manufacturing and public administration as indicated by the location quotient. Both of these industries have relatively small discrimination coefficients. Furthermore, the industry in which the west region gained the largest share, namely, retail trade, also has a relatively small discrimination coefficient. Although the west region lost share in construction (which has a discrimination coefficient close in value to the "market" discrimination coefficient), it registered sizeable gains in regional share in three of the four industries with the largest discrimination coefficients, namely, nondurable manufacturing, other transportation and wholesale trade. This is particularly disturbing since the hypothesis would predict a decline in the

TABLE 5

INDUSTRY DISCRIMINATION COEFFICIENTS AND CRITICAL LEVELS OF SIGNIFICANCE

\begin{tabular}{lcc}
\hline INDUSTRY & COEFFICIENT $^{\mathrm{b}}$ & CRITICAL LEVEL $^{\mathrm{a}}$ \\
\hline CONSTRUCTION & .12179 & $.002 \mathrm{D}-0 \mathbf{1}^{\mathrm{c}}$ \\
DURABLE MANUFACTURING & .09375 & $.001 \mathrm{D}-03$ \\
NONDURABLE MANUFACTURING & .13265 & $.003 \mathrm{D}-04$ \\
OTHER TRANSPORTATION & .13462 & $.005 \mathrm{D}-01$ \\
OTHER UTILITIES & .16873 & .002 \\
WHOLESALE TRADE & .14787 & .004 \\
RETAIL TRADE & .08496 & .02 \\
EDUCATION & .09908 & .003 \\
PUBLIC ADMINISTRATION & .10539 & $.003 \mathrm{D}-01$ \\
MARKET COEFFICIENT & .12855 & .005 \\
\hline
\end{tabular}

${ }^{a}$ Critical level of significance for which the hypothesis that the coefficient of discrimination is insignificantly different from zero would be rejected in a one-tailed test.

bIn natural logarithms.

'Read as .0002. 
relative wage and salary income of black males which runs counter to the slight increase suggested in Table $1 .^{15}$

In the northeast region, the location quotient identified other transportation, public administration and retail trade as being mainly responsible for the magnitude of the coefficient of specialization in 1970. The first of these industries has the largest discriminatin coefficient of all industries while the other two have relatively small coefficients. What is significant, however, is that although this region gained a larger share in retail trade (which has a relatively small discrimination coefficient), it (more importantly) lost regional share in both durable manufacturing and nondurable manufacturing. It is conceivable, therefore, that some of these changes produce off-setting effects such that the net impact on the black-white wage and salary ratio is neutral. While we could not accept the hypothesis on this score, we could not reject it either.

Finally, in considering the north-central region, we found it to be most specialized in durable manufacturing and public administration (in 1970). Both of these industries have relatively small discrimination coefficients. Moreover, the largest gain in share in this region was registered in durable manufacturing. The north-central region does show a gain in share of other transportation and wholesale trade-two industries with relatively large discrimination coefficients. Nonetheless, this region experienced a notable loss in regional share of nondurable manufacturing and a less sizeable loss of other utilities. Again, it is quite plausible that these changes could nullify one another in such a manner that the relative wage and income of black males in this region remains fairly constant or even possibly increase. In checking with Table 1, we find this to be the case. Once more, we are unable to unquestionably accept the hypothesis but we are also unable to reject it.

\section{Quantitative}

Notwithstanding the seemingly important influence of changes in industrial composition and industry discrimination coefficients on the differential advances in black-white earnings (wages) across regions, the evidence presented thus far-while employing some descriptive measures - is primarily qualitative in nature. It would no doubt be instructive to quantify these findings. Given the limitations imposed by the data, such a comprehensive quantification of the evidence is not feasible. However, it is possible to isolate and measure the ceteris paribus effects of changes in regional discrimination brought about by shifts in industrial composition. The computation of this measure, however, labors under the same simplifying assumptions governing the qualitative results reached above. The procedure involves the weighting of the industry discrimination coefficients by the shares of employment in the region for each industry and then summing over all industries. The resulting coefficient may be interpreted as the average wage discrimination in the region. Two such coefficients can be calculated for each region using the 1960 and 1970 census employment data. If, for each region, the 1960 regional discrimination coefficient is subtracted from the 1970 coefficient, the resulting mea- 
sure represents the desired change, namely, the effects of changes in employment patterns (i.e., industry shares of regional employment) holding industry discrimination constant. This procedure may be represented conceptually as follows:

For Region j -

(1) $\frac{\sum e_{i j}^{1960}}{\mathrm{i} \mathrm{e}_{\mathrm{ij}}^{1960}} \mathrm{D}_{\mathrm{in}}^{1973}=\hat{\overline{\mathrm{D}}}_{\mathrm{j}}^{1960}$
(2) $\sum_{\mathrm{i}{ }_{\mathrm{ij}}^{1970}}^{\mathrm{e}_{\mathrm{tj}}^{1970}} \mathrm{D}_{\mathrm{in}}^{1973}=\tilde{\overline{\mathrm{D}}}_{\mathrm{j}}^{1970}$

and

$$
\Delta \overline{\mathrm{D}}_{\mathrm{j}}=\tilde{\overline{\mathrm{D}}}_{\mathrm{j}}^{1970}-\hat{\overline{\mathrm{D}}}_{\mathrm{j}}^{1960}
$$

where:

$\mathrm{e}_{\mathrm{ij}}=$ employment in the $\mathrm{i}^{\text {th }}$ industry in the $\mathrm{j}^{\text {th }}$ region.

$e_{t j}=$ total employment in the $j^{\text {th }}$ region.

$\mathrm{D}_{\mathrm{in}}^{1973}=$ the industry discrimination coefficient for the $\mathrm{i}^{\text {th }}$

$\hat{\bar{D}} \quad$ industry computed from the 1973 CPS data tape.

$\hat{\overline{\mathrm{D}}}_{j}^{1960}=$ average wage discrimination in the region in 1960 using 1960 employment shares and 1973 industry discrimination coefficients.

$\tilde{\overline{\mathrm{D}}}^{1970}=$ average wage discrimination in the region in 1970 using 1970 employment shares and 1973 industry discrimination coefficients.

$\Delta \overline{\mathrm{D}}_{\mathrm{j}}=$ The change in the average wage discrimination in the region attributable to changes in industry composition (holding industry discrimination constant). ${ }^{16}$

In accordance with the aforementioned procedure, estimates were obtained for $\hat{\overline{\mathrm{D}}}_{\mathrm{j}}{ }^{1960}, \tilde{\overline{\mathrm{D}}}^{1970}$, and $\Delta \overline{\mathrm{D}}_{\mathrm{j}}$ for the four census regions. These results are presented in Table 6 . The regional estimates for both $\hat{\bar{D}}^{1960}$ and $\tilde{\overline{\mathrm{D}}}^{1970}$ range from approximately .109 to .113. The estimates of $\Delta \overline{\mathrm{D}}_{\mathbf{j}}$, on the other hand, are smaller in magnitude ranging from -.008 to -.005. Even

TABLE 6

REGIONAL WAGE DISCRIMINATION AND THE EFFECTS OF CHANGES IN INDUSTRIAL COMPOSITION

\begin{tabular}{lccc}
\hline REGION & $\hat{\overline{\mathrm{D}}}^{1980}$ & $\tilde{\overline{\mathrm{D}}}^{1970}$ & $\Delta \overline{\mathrm{D}}$ \\
\hline NEAST & .11173 & .11097 & -.00076 \\
SOUTH & .11344 & .11297 & -.00047 \\
WEST & .11066 & .10985 & -.00081 \\
NCENT & .10937 & .10872 & -.00065 \\
\hline
\end{tabular}


though these latter estimates are small in size, they reveal at least three noteworthy features. First of all, their size suggests that the "true" effects no doubt are similarly small in magnitude. Secondly, they are all negative thus implying that changes in industrial composition had a favorable (i.e., reducing) but differential effect on the average regional wage discrimination for all four census regions between 1960 and 1970. Finally, changes in industrial composition represent only one of the structural components of the total change, albeit an important one, which occurred during the period. Nonetheless, the resulting estimates might be regarded as significant, even if modest in magnitude.

\section{CONCLUSIONS}

Given the limitations (both explicit and implicit) imposed by the data, the comparative evidence seems to suggest that the theme of the hypothesis advanced here is probably an important influence on the regional changes in the relative wages and salary income of black males during the period of the sixties. To the extent that the results obtained here underscore any policy directives, the message suggests the enactment of antidiscrimination policies which are more regionally oriented. Moreover, the empirical results point to the need for more detailed studies on individual industries in order to more accurately characterize their regional pay patterns and possible discriminatory behavior.

Regional disparities in the relative wage and salary advances of blacks most assuredly demand more attention than has been forthcoming. Hopefully, the effort expended here will stimulate more interest in this area.

FOOTNOTFS

'See, for example' Flanagan [5]. Freeman [6], and King and Marshal [10].

${ }^{2}$ Table 1 presents an overall view of the uneven pattern of advance in the relative wage and salary income of black males (as compared to their white counterparts) across regions for 1959 and 1969 . The differential rates of progress in the relative earnings of black males is evident. The data indicate virtually no change in the relative position of black males during the sixties in the Northeast and North (entral regions. On the other hand. black males experienced large gains in the South and rather modest advances in the W'est.

${ }^{3}$ Such viewpoints may be found in Flanagan [5]. Freeman [6], and Wohlstetter and Coleman [17].

The nine industries used in this study are : construction, durable manufacturing. nondurable manufacturing. other transportation, other utilities, wholesale trade. retail trade, education, and public administration. For more on their selection see footnote

${ }^{5}$ The limiting values of this coefficient are 0 and 1 . The coefficient will take on the value of 0 if the region has an identical proportional mix of industries as the U.S. as a whole. On the other hand, if all the employment of the region is concentrated in one industry, then the coefficient takes on the value of 1 . Thus, as a simple rule of thumb, a high or large coefficient implies specialization and a low or small coefficient implies diversification. The evaluation of this statistic is as follows:

If $L Q>1$ : the region is more specialized than the base (i.e., the U.S.) in the study industry.
If $I . Q<1$ : the region is less specialized than the base in the study industry.

If $I . Q=1:$ the region and the nation specialize 6 an equal degree in the study industry.

${ }^{7} \mathbf{F}$ or an clementary presentation of the shift-share technique, see Perloff $[6]$.

"The shift-share technique is a descriptive tool and not at theory of industrial or regional growth. Its use in the regional economic literature has been criticized by some and supported by others. For a very informative critique of shift-share analysis, see D. Houston [9]. For an equally persuasive defense of the technique. see $I$. Ashby [1].

${ }^{9} T$ he industry-mix effect reflects the distribution of regional employment among rapid-growth and slowgrowth industries relative to the industry-mix which prevails in the nation. The rationale underlying this effect is as follows: as the nation grows, some industries grow more rapidly than others; therefore, a region specializing in slow-grow th industries will show a net downward shift in employment while a region containing a high portion of rapid-growth industries will show an upward shift.

The local market or share effect. on the other hand. accounts for the fact that industries grow in some regions faster than in others. Thus, this effect indicates the influence on regional growth resulting from a given industry or industries in the region growing at a different rate than its national (industry) average. In doing so. it allows us to gauge whether a region is gaining an 
increasing proportion of an industry or industries as a result of "within-industries" changes.

${ }^{10} \mathrm{It}$ is useful to note that the discrimination coefficients employed here are presumed to vary across industries and that there exist an empirical and theoretical basis for this supposition. On the empirical side, researchers have shown that the discriminatory behavior of firms, and thus industries, are differentially affected by such variables as firm size (see, e.g., Ashenfetter and Heckman [3]. and Goldstein and Smith [7]), firm growth (see Burman [4]), the extent of unionization (see Ashenfetter [2]), and the presence of government contracts (see among others. Ashenfetter and Heckman [3], and Heckman and Wolpin [8]). From a theoretical point of view, some purely theoretical models tend to predict such industry differences in discrimination coefficients for example, see M. M. Smith [14].

For a detailed presentation of the industry discrimination coefficients discussed here, see M. M. Smith [13]. ${ }^{1}$ The industries examined were selected on the basis of containing at least 50 observations for each race group after the elimination of individual cases which did not record information for all of the key variables contained in the regression analysis. Therefore, the choice of the resulting nine industries was determined by the preceeding criteria and the configuration of the data.

${ }^{12}$ This estimating equation of the wage structure is a modified version of the basic human capital equation used by most researchers. The specification includes the usual human capital characteristics and other explanatory variables such as race, education, work experience marital status. size of urban area, region, occupation. and union status

${ }^{13}$ Houston [9].

${ }^{1}$ The following statistic was used to test the significance of the industry discrimination coefficients:

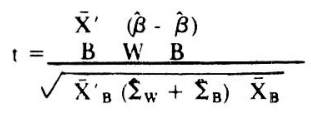

where:

$\bar{X}_{B}=$ a vector of mean characteristics of black workers

$\hat{\beta}_{W}\left(\hat{\beta}_{B}\right)=$ a vector of the estimated regression coefficients from the white (black) regression

$\Sigma_{\mathrm{w}}=$ estimated $\operatorname{var}\left(\hat{\beta}_{\mathrm{W}}\right)$

$\mathcal{\Sigma}_{\mathbf{B}}=$ estimated $\operatorname{var}\left(\hat{\beta}_{\mathbf{B}}\right)$

and the assumption that $\operatorname{COV}\left(\beta_{\mathbf{w}}, \beta_{\mathbf{B}}\right)=0$. For more on this test statistic, see Smith [12].

${ }^{15}$ As we observed earlier, the west region experienced the largest percentage growth rate of all the regions. It is quite possible that there exists some large scale growth effect which swamps the depressing effects predicted by the hypothesis and thus causing the black-white wage and salary ratio to increase slightly.

${ }^{16}$ As previously stated, the computation of $\Delta \bar{D}_{1}$ is not without some qualifications. Implicitly assumed in this measure is that the various industry discrimination coefficients $\left(D_{\text {in }}\right)$ do not change between the two periods and that the discrimination coefficient for the $i$ th industry is the same for all regions. It should be further noted that in the estimation of the individual industry discrimination coefficients, region, inter alia, was controlled for. As such, the resulting coefficients would more appropriately be regarded as national industry discrimination coefficients-hence, the $\mathrm{n}$ in $\mathrm{D}_{\mathrm{ln}}$. This is particularly noteworthy since, in the main, regional variation in black-white differences and the like are taken into account.

\section{REFERENCES}

1. Ashby, L. D. "The Shift and Share Analysis: A Reply." The Southern Economic Journal, 34 (1968), 423 25.

2. Ashenfetter, O. "Racial Discrimination and Trade Unionism," Journal of Political Economy, (1972), 4.35-464.

3. Ashenfetter, O. and Heckman, J. "Measuring the Effect of an Anti-Discrimination Program," in Orley Ashenfetter and James Blum, eds., Evaluating the Labor Market Efferts of Social Programs. Princeton, N.J.: Princeton University Press, 1976.

4. Burman. C. The Economics of Discrimination: the Impact of Public Policy, Unpublished Ph.D. dissertation. University of Chicago, 1973.

5. Flanagan. R. J. "Actual Versus Potential Impact of Government Ant-Discrimination Programs,"Industrial and Labor Relations Revieu, 29 (1976), 486-507.

6. Freeman, R. B. "Changes in the Labor Market for Black Americans, 1948-72," Brookings Papers on Economic Activity, 1 (1973), 67-120.

7. Coldstein, M. and Smith, R. S. "The Estimated Impact of the Anti-Discrimination Program Aimed at Federal Cont ractors," Industrial and Labor Relations Revieu, (1976), 523-543.

8. Heckman, J. and Wolpin, K. "Does the Contract Compliance Program Work? An Analysis of Chicago Data," Industrial and Labor Relations Review, (1976), 544-564.

9. Houston, D. B. "The Shift and Share Analysis of
Regional Growth: A Critique," The Southern Economic Journal, 33 (1967), 577-81.

10. King, A. G. and Marshall, R. "Black-White Economic Convergence and the Civil Rights Act of 1964," Industrial Relations Research Association Proceedings, (Spring 1974), 462-71.

11. Perloff, S. H. "Comparing Municipal Salaries with Industry and Federal Pay," Monthly Labor Review, 94 (1971).

12. Smith, M. M. “A Note On Tests of Significance and Wage Discrimination," The American Economist, forthcoming.

13. "Industrial Racial Wage Discrimination in the U.S.," Industrial Relations, 18 (1979), 110-116.

14. "Towards a General Theory of Racial Wage Discrimination," Southern Economic Journal, 45 (1978), 458-468.

15. Vroman, W. "Changes in Black Workers' Relative Earnings: Evidence from the 1960s," in von Furstenberg, G. M., Horowitz, A. R. and Harrison, B., eds., Patterns of Racial Discrimination, Lexington, Mass.: D. C. Heath and Co., 1974.

16. Welch, F. "Labor Market Discrimination: An Interpretation of Income Differences in the Rural South," Journal of Political Economy, 75 (1967), 22540.

17. Wohlstetter, A. and Coleman, S. "Race Differences in Income," in Pascal, A., ed., Racial Discrimination in Economic Life, Lexington, Mass.: D. C. Heath and Co., 1972. 